\title{
THE PHYTOCOENOSES OF ANTHROPOGENICALLY TRANSFORMED AREAS WITH A GREAT IMPORTANCE FOR APOIDEA
}

\author{
${ }^{1}$ Malgorzata Wrzesień, ${ }^{2}$ Bożena Denisow
'Department of Geobotany , Institute of Biology, Maria Curie-Skłodowska University, Akademicka 19, 20-033 Lublin, Poland, e-mail: mseptember@tlen.pl
${ }^{2}$ Department of Botany, Agricultural University in Lublin, \\ Akademicka 15, 20-950 Lublin, Poland. e-mail: bozena.denisow@ar.lublin.pl
}

Received: 20.09.2007

\section{$\mathrm{Su} \mathrm{m} \mathrm{m}$ a r y}

The paper indicates the phytocenoses most rich in bee taxons and occurring in habitats located along railway lines crossing Lublin Upland. To date, in the study area 124 basic phytocoenoses have been discovered, described and classified into 12 different synecological groups. Among 52 phytocoenoses, the participation of bee flora was considerable. Most voluble phytocoenoses represent ruderal and segetal associations (Artemisietea vulgaris, Stellarietea mediae classes - 87 species), meadow and pasture associations (Mollinio-Arrhenatheretea - 56 species), psammophilous and xerothermic grasslands (FestucoBrometea, Koelerio glauce-Corynophoretea canescensis - 38 species), thermophilous forest edge communities and thickets (Trifolio-Geranietea and Rhamno-Prunetea - 33 species). Significantly fewer melliferous and polleniferous taxons were noticed in mesophilous deciduous forests or thermophilous oak forests - 29 species. Most simple in structure and species richness are associations with Rumex acetosa, Reseda lutea, Linaria vulgaris, Papaver rhoeas, Cirsium arvense, Oenothera biennis, Viola arvensis and Potentilletum anserine or Sisymbrietum altissimi. The communities form patches $\left(15-20 \mathrm{~m}^{2}\right)$ with $80-100 \%$ cover of the diagnostic taxon and are of low or medium stability. The most persistent and floristically stable are Tanaceto Artemisietum, Rudbeckio-Solidaginetum, Echio-Melilotetum, Sambucetum nigrae, Rubo fruticosi-Prunetum spinosae and communities with Rosa rugosa, Rubus caesius, Geranium robertianum, Pastinaca sativa, Trifolium medium or Euphorbia cyparissias. The maintenance of the mosaic of phytocoenoses in anthropogenically transformed habitats, including those along railway lines, is of decisive importance for the protection of floristic diversity and adaptation processes of Apoidea.

Key words: railway areas, bee flora, synecological groups, central-eastern part of Poland

\section{INTRODUCTION}

There is a general understanding of the fact that due to human activities biodiversity is threatened on a global scale, and it concerns species, populations and also the ecosystem level. The negative changes in different environmental components cause the shrinkage of natural habitats and influence particularly organisms of high sensitivity, such as insects (K o r n e r, 2005). Populations decrease among them or even extinctions of pollinator species have been documented widely across Europe, including Poland (B a n a s z a k, 1992; C a rr e c k and Willi a m s, 1998). The lack of pollinators affect entomophilous crops causing great economical loses on a big scale ( $\mathrm{Z} \mathrm{y} \mathrm{ch}$ and $\mathrm{J} \mathrm{ak} \mathrm{ubie} \mathrm{c,} \mathrm{2006).}$ The shrinkage of available forage reserves is considered to be a main factor limiting bee populations. Thus, basic flora records perform an important part in the estimation of natural resources for bees. Nectariferous and polleniferous species are fundamental for apiaries and essential as food resources for different wild Apoidea (J a błoński and Kołtowski, 1995). Studies on the distribution of bee flora proved that many of these species occur in highly transformed anthropogenic habitats, such as road sides, sandpits, railway tracts, quarries, ruderal sites in urban areas (Wrzes i en and D e n i s o w, 2006 a,b).

The present paper deals with the analysis of railway flora which constitutes a permanent anthropogenic element in natural landscape of most regions in Poland. Railway lines are characterized by an exceptional mosaic of habitats since they run across open areas, meadows, agrocoenoses, compact forest complexes and urban areas. The areas under consideration make excellent migration routes for diasporas of various species; among them are taxons of potential value as a food source for Apoidea. Thus phytocoenoses located along railway tracks are important as the main or supplementary source of food for pollinators nesting there or just penetrating the area. Phytosociological analyses can document how communities are structured and can show what may be consequences of biodiversity losses for entire ecosystems. 
The main reason of the investigations was to indicate phytocoenoses in railway areas of the greatest importance as the sources for nectariferous and polleniferous taxons. Special attention was paid to the abundance of insect visitors in the analyzed phytocoenoses.

\section{MATERIALS AND METHODS}

The data concern both floristic and phytosociological richness of railways areas. The paper is based on own, published or unpublished, studies, which were conducted since 1998, including the Lublin Upland, Roztocze, Polesie and Volhynia Upland (Fig. 1). The studied area was divided into 883 incomplete squares of ATPOL units which belong to 83 squares with $10 \mathrm{~km}$ long sides ( $\mathrm{Z}$ a j a c , 1978). The analyses of flora covers all types of habitats related to railway lines, with the total length of about $900 \mathrm{~km}$, and it includes railway tracks, cargo yards, ridges and embankment slopes, trenches and drainage ditches as well as edges of the nearby semi-natural communities.

The phytocoenoses found in the areas under consideration were classified into synecological groups according to C e $1 \mathrm{k} \mathrm{a}$ (2004) and J a c k o w i a k (1990, 1993) and linked to syntaxons of higher units (classes, orders and alliances). The syntaxon determination was based on M a t u s z k i e w i c z (2001) and Z a r z y c k i et al. (2002). The synecological units represented by typical associations with diagnostic species (characteristic or differential) of high density and preferred by Apoidea are shown in Table 1. The average patch area, stability, location of stations and frequency are given for each phytocoenosis. The phenology of phytocoenoses based on the intensity of pollinator visits, which is in close relation with abundance of most valuable forage taxons, is presented in Table 2. The blooming stages were established according to an assumption that the beginning of blooming was the moment when $10 \%$ of flowers bloomed, the full bloom stage being $70-80 \%$ of flowers in bloom, and the end with over $75 \%$ of flowers came out of bloom.

\section{RESULTS}

The spontaneous flora of railway areas in the middle-eastern part of Poland consists of 950 angiosperms taxons. In the landscape under consideration, 124 basic phytocoenoses were discovered and described (Wrzesień and Święs, 2006). Among 52 chosen phytocoenoses, as many as 324 flow species were noticed. The phytocoenoses under consideration belong to different synecological groups and mainly represent ruderal and segetal associations (Artemisietea vulgaris, Stellarietea mediae classes - 87 species), meadow and pasture associations (Mollinio-Arrhenatheretea - 56 species), psammophilous and xerothermic grasslands (Festuco-Brome- tea, Koelerio glauce-Corynophoretea canescensis - 38 species), thermophilous forest edge communities and thickets (Trifolio-Geranietea and Rhamno-Prunetea - 33 species), rarely mesophilous deciduous forests or thermophilous oak forests - 29 species (Tab. 1, Fig. 2). Plants species occur as single individuals, create loose patches or are dominants in the analyzed phytocoenoses. Among the recorded phytocoenoses, in which polleniferous or nectarifeous taxons are of great participation, most simple in structure and species richness are communities with Rumex acetosa, Reseda lutea, Linaria vulgaris, Papaver rhoeas, Cirsium arvense, Oenothera biennis, Viola arvensis and Potentilletum anserine or Sisymbrietum altissimi associations. The communities form patches $\left(15-20 \mathrm{~m}^{2}\right)$ with $80-100 \%$ cover of the diagnostic taxon and are of low or medium stability. The floristic composition of the phytocoenoses does not provide the possibility of survival for insects for a long time. At different seasonal stages, bees penetrate there, migrating from trophically poorer ecosystems. The density of pollinators in the phytocoenoses increases significantly at full bloom stage (Figs 3, 4). Mosaics of phytocoenoses in landscape form a rich source of food supply for meliophages and create an uninterrupted chain of nectar and pollen from early spring to late summer.

The most persistent and floristically stable are Tanaceto-Artemisietum, Rudbeckio-Solidaginetum (Fig. 5), Echio-Melilotetum, Sambucetum nigrae, Rubo fruticosi-Prunetum spinosae associations and communities with Rosa rugosa, Rubus caesius, Geranium robertianum, Pastinaca sativa, Trifolium medium or Euphorbia cyparissias (Fig. 6). The phytocoenoses form wide $\left(20-50 \mathrm{~m}^{2}\right)$ patches and occupy the same location year after year, if only any human factor does not cause any habitat modification. The phytocoenoses with apparently poor herbaceous vegetation (e.g. Sambucetum nigrae, Rubo fruticosi-Prunetum spinosae) create refuge and nesting places for all potential pollinators, additionally supporting the flow.

The phytocoenoses with a high share of flow species most often prefer railway embankments and slopes where the habitat is similar to natural and almost not converted by humans (com. with Thymus serpyllum, with Astragalus cicer, with Euphorbia cyparissias or with Galium verum). The railway edges are usually covered by phytocenoses with kenophytes as diagnostic species (Bunietum orientalis (Fig. 7), Helianthemum tuberosi, com. with Galinsoga parviflora and G. ciliata).

Most of the remaining phytocoenoses which developed in the study area were connected with different habitats. That proves the existence of different strategies as high potential mobility or rapid adaptation possibilities of plant species to overcome the enormous pressure of man. The pressure usually relates to different changes of environmental habitat conditions, mainly physical 


\begin{tabular}{|c|c|c|c|c|c|c|c|c|c|c|c|c|c|c|c|c|c|c|}
\hline 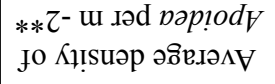 & - & $m$ & $m$ & $\nabla$ & $\overrightarrow{0}$ & $N$ & in & $m$ & $n$ & 6 & N & $\nabla$ & - & - & $n$ & $\sim$ & $\sim$ & $n$ \\
\hline 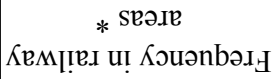 & \pm & - & 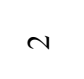 & - & $N$ & $N$ & 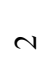 & $N$ & $m$ & - & - & $N$ & $n$ & - & $N$ & $\sim$ & - & - \\
\hline 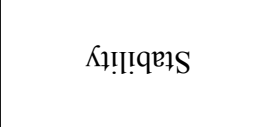 & U & 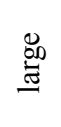 & 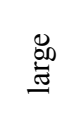 & $\underset{\Xi}{\Xi}$ & 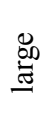 & : & $\begin{array}{l}0 \\
\text { 离 } \\
\text { ] }\end{array}$ & 总 & 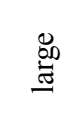 & 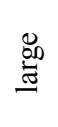 & 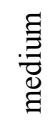 & :尹马 & $\begin{array}{l}0 \\
\text { क्D } \\
\text { ] }\end{array}$ & 离 & 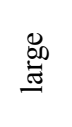 & 苾 & 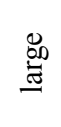 & $\underset{\Xi}{\Xi}$ \\
\hline 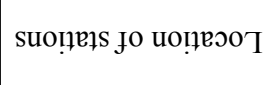 & I & 0 & $0^{\circ}$ & $0^{2}$ & 0 & 0 & 0 & $0^{n}$ & $\ddot{0}$ & $\infty$ & 0 & 0 & $\tilde{0}$ & $\tilde{0}^{2}$ & $\infty$ & 0 & 0 & $\tilde{0}^{n}$ \\
\hline 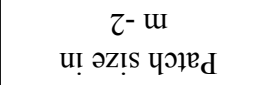 & 되 & 요 & $\stackrel{\infty}{\sim}$ & 고 & $\approx$ & $\stackrel{\infty}{-}$ & in & 요 & 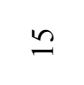 & 으 & $\simeq$ & 으 & 2 & $\cong$ & ิㅗ & 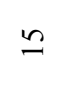 & $ㅇ$ & 으 \\
\hline 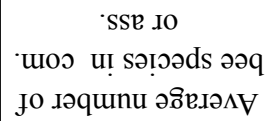 & $\theta$ & 으 & \pm & 고 & ส & $\cong$ & 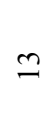 & 구 & ㄱ. & 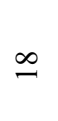 & 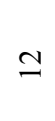 & 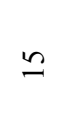 & $\stackrel{\infty}{m}$ & $\vec{\sim}$ & i & $\hat{\sim}$ & $=$ & 으 \\
\hline 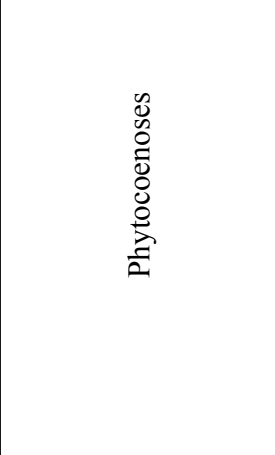 & u & 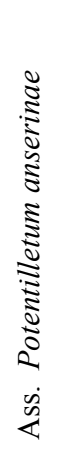 & 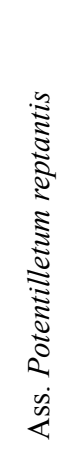 & 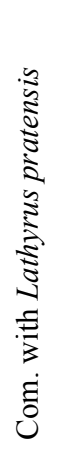 & 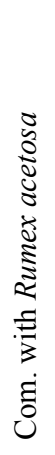 & 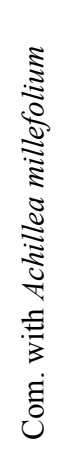 & 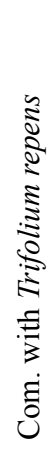 & 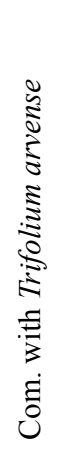 & 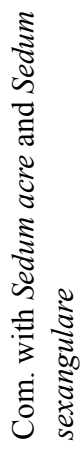 & 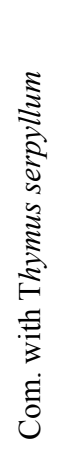 & 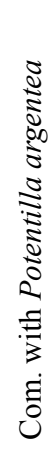 & 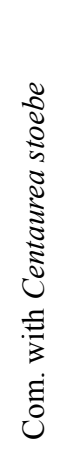 & 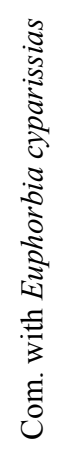 & 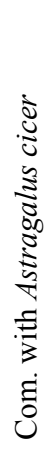 & 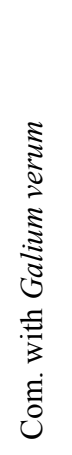 & 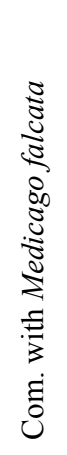 & 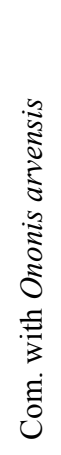 & 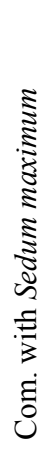 \\
\hline 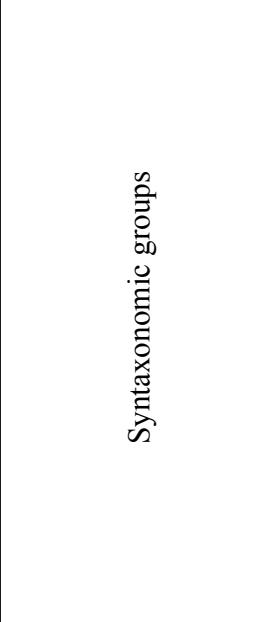 & 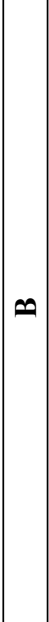 & & 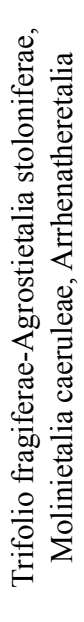 & 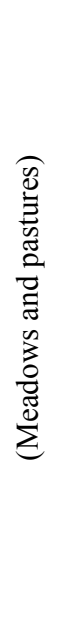 & & & & & 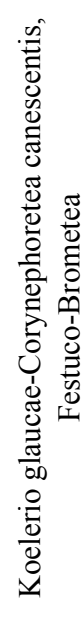 & 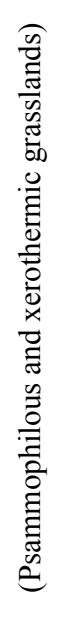 & & & & & 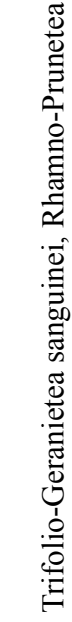 & 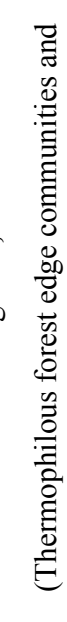 & $\begin{array}{l}\frac{\partial}{0} \\
0 \\
0 \\
0 \\
= \\
=\end{array}$ & \\
\hline z & $\varangle$ & \multicolumn{6}{|c|}{-} & \multicolumn{6}{|c|}{ i } & \multicolumn{5}{|c|}{$\dot{r}$} \\
\hline
\end{tabular}




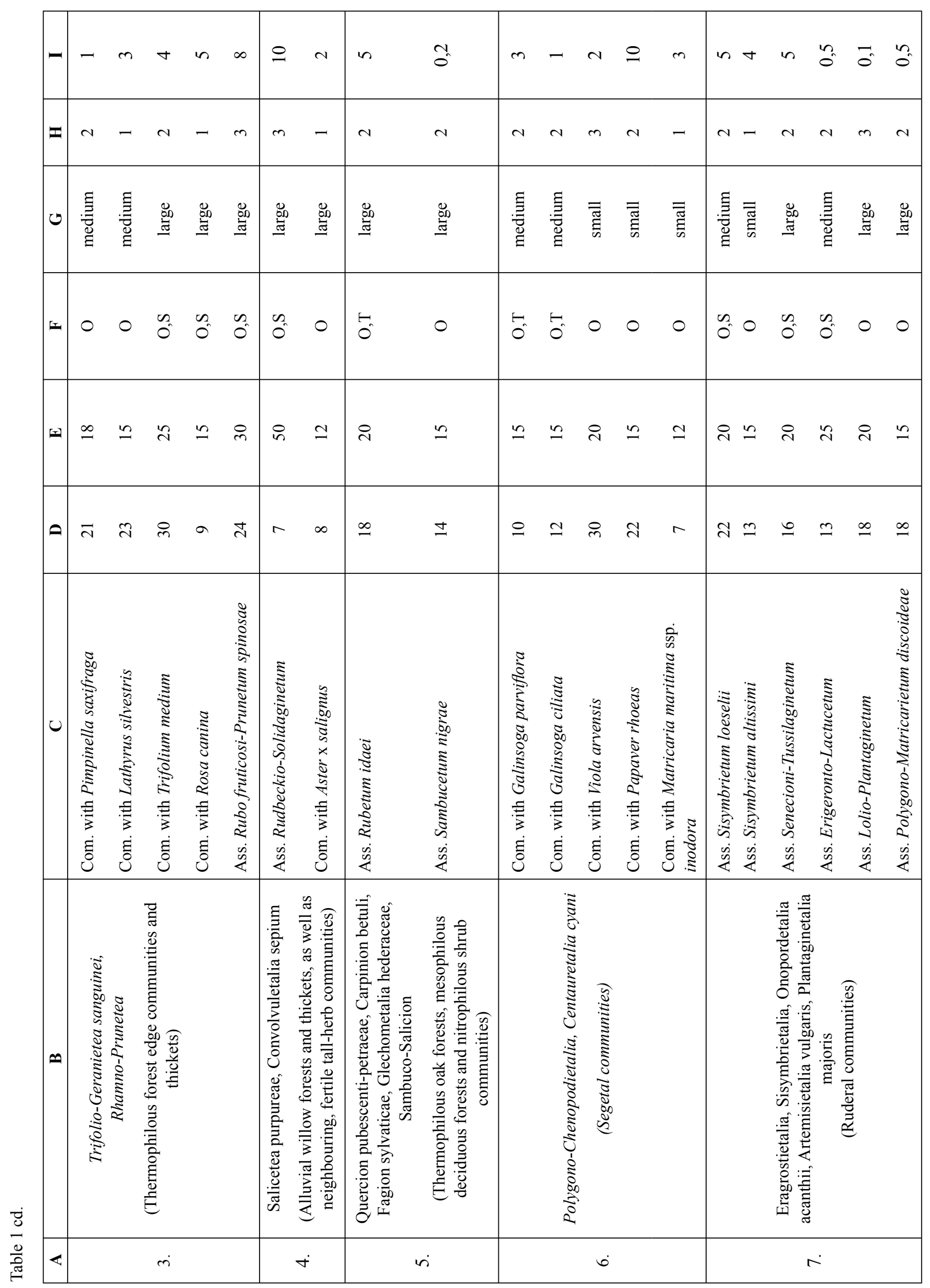




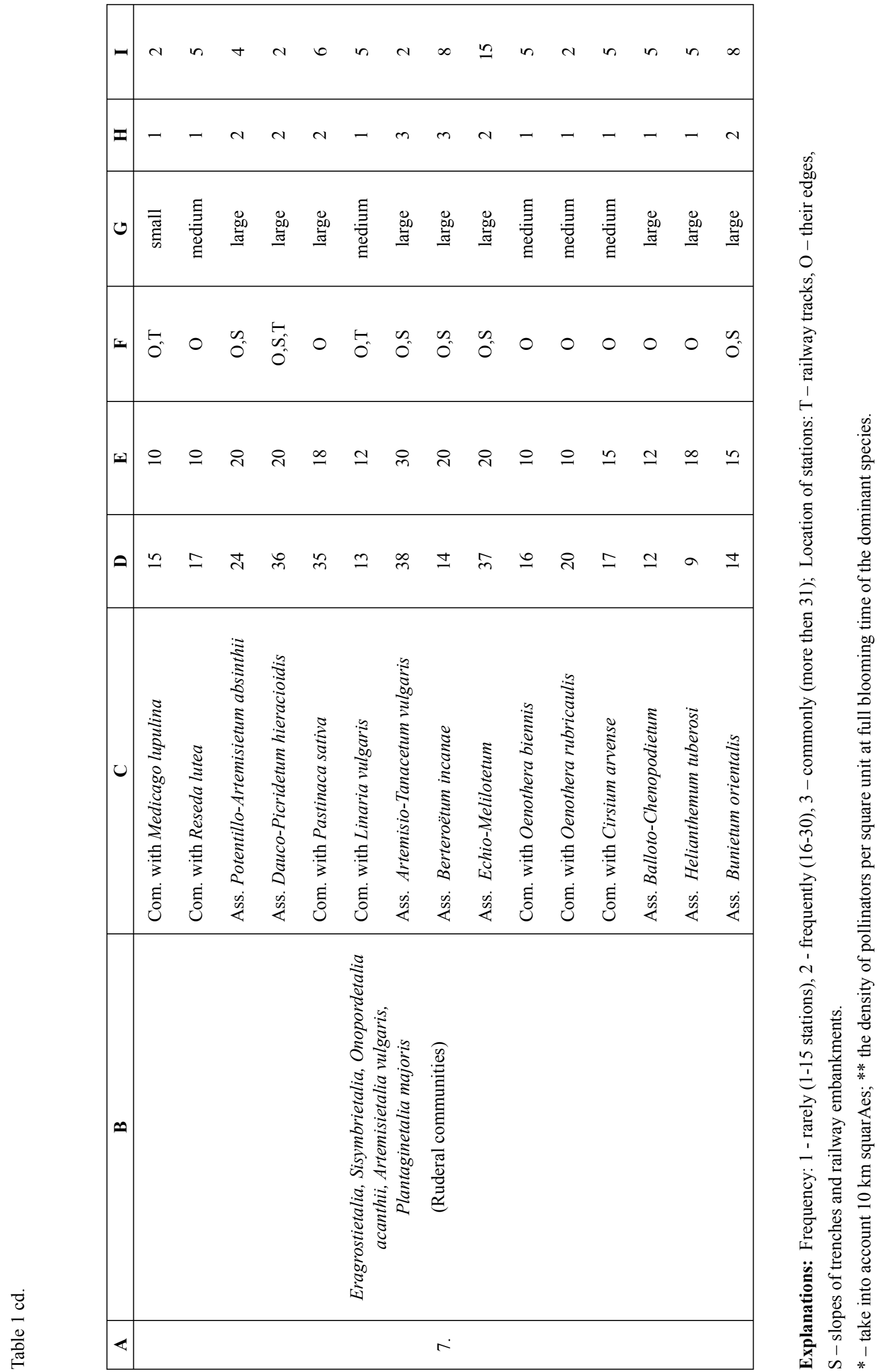




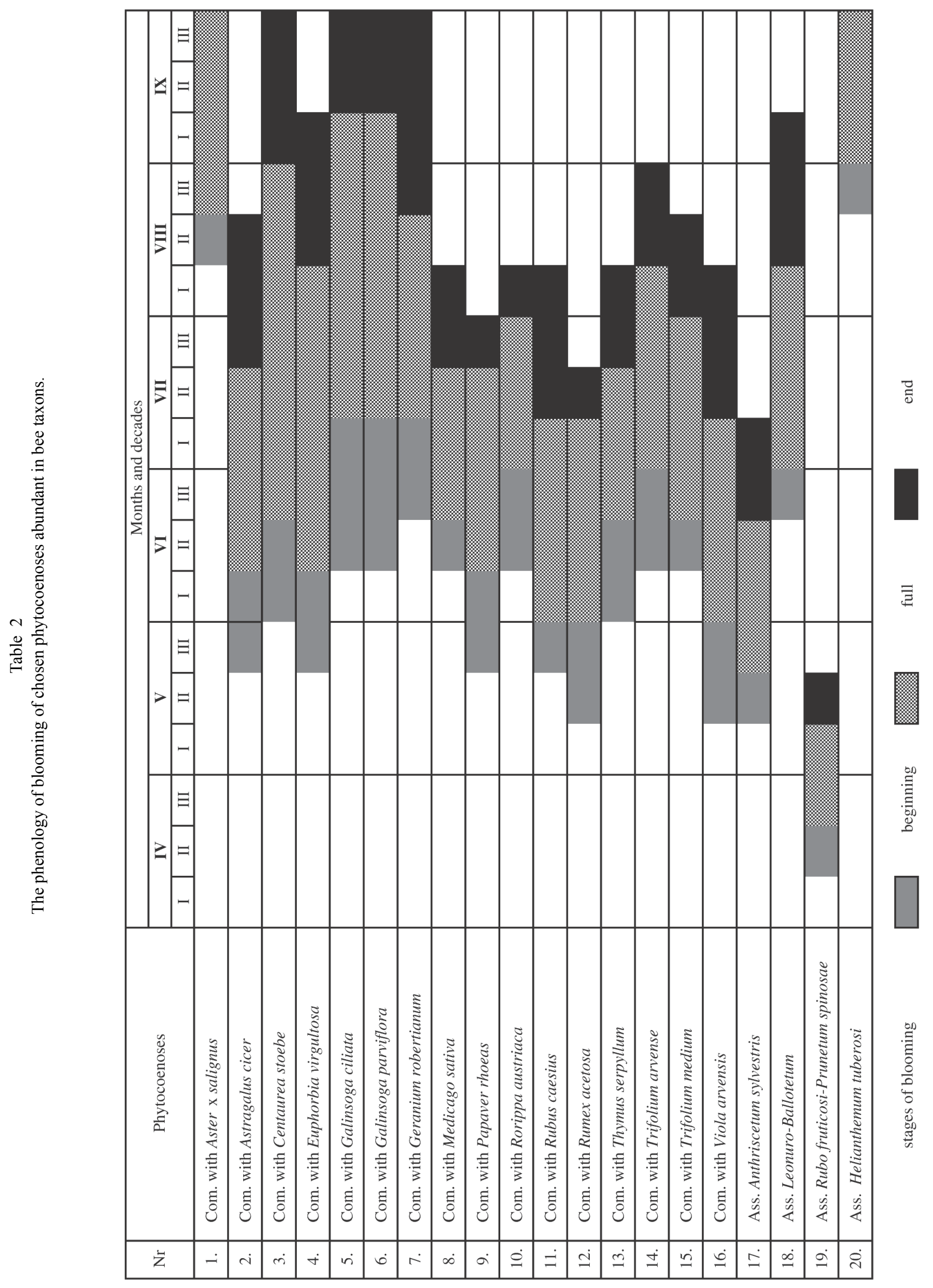




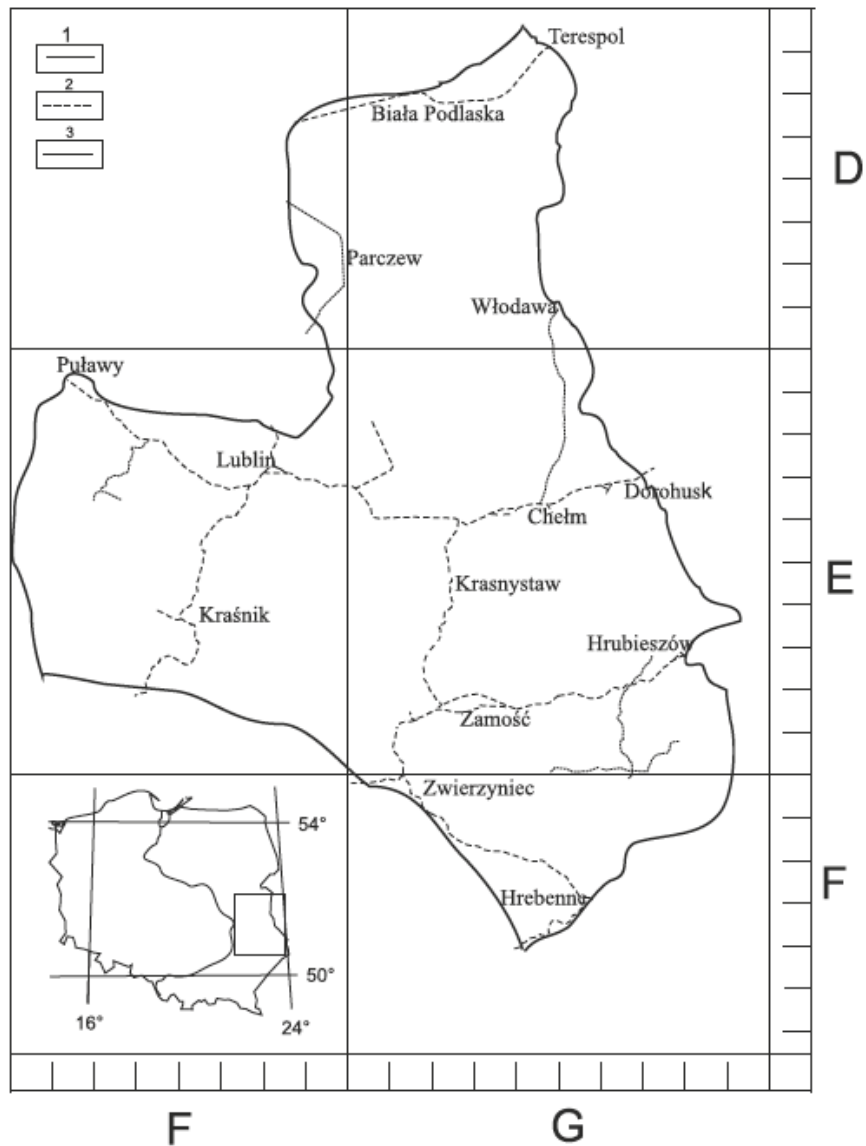

Fig. 1. Location of the study area. 1 - borders of the region, 2 - working railways, 3 - closed railways.

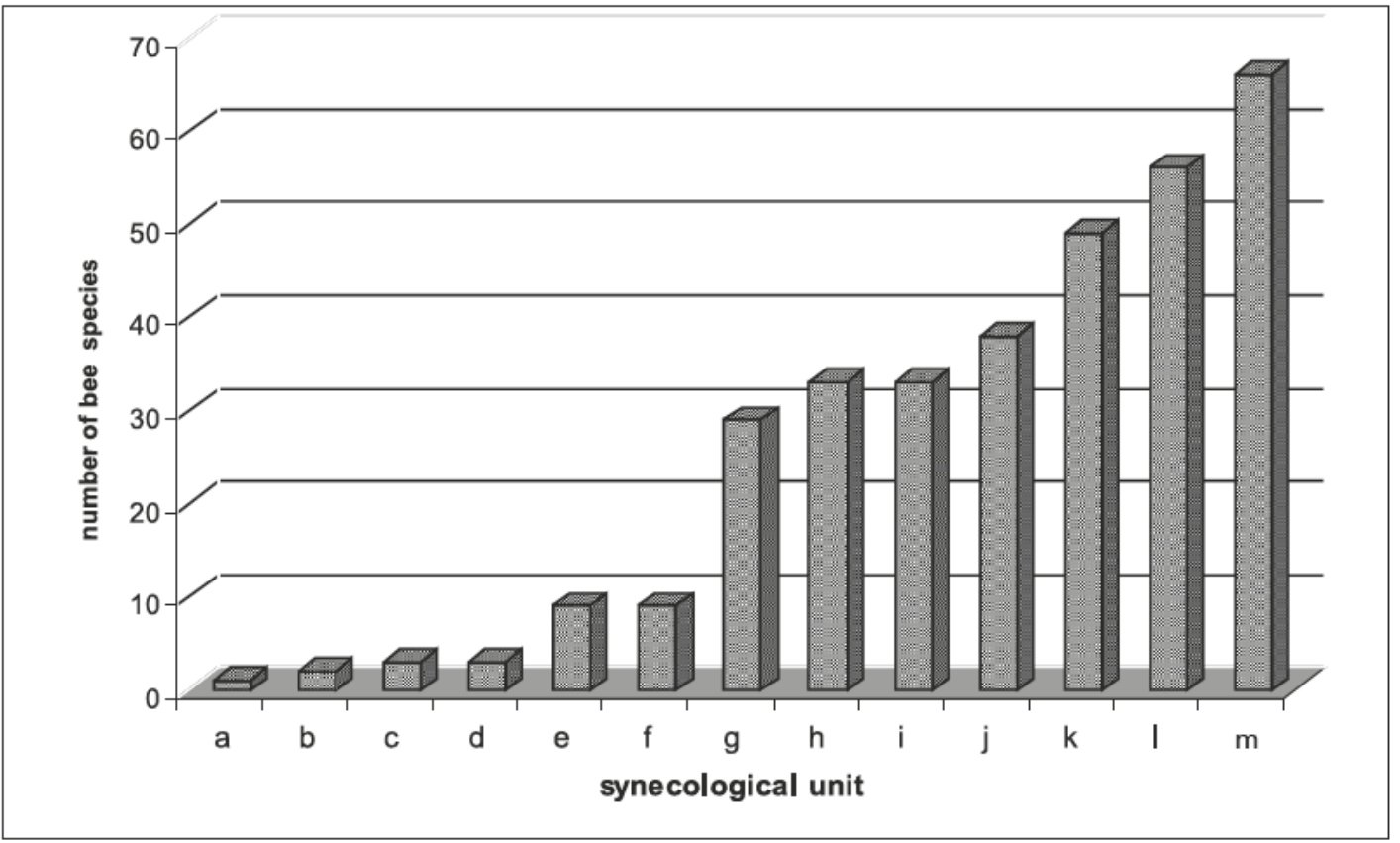

Fig. 2. The participation of flow taxons in synecological units on studied railway areas: a - mesotrophic bogs' communities, b-boggy and riparian alder forests and thickets, $\mathrm{c}$ - therophytic communities of slimy grounds, $\mathrm{d}$ - alluvial willow forests and thickets, as well as neighbouring, fertile tall-herb communities, $\mathrm{e}$ - poor pine stands and acidophilous oak forests, $\mathrm{f}$ - acidophilous heathlands and herbaceous communities developing in the forest gaps and clearings, $g$ - thermophilous oak forests, mesophilous deciduous forests and nitrophilous shrub communities, $\mathrm{h}$ - segetal communities, $\mathrm{i}$ - thermophilous forest edges' communities and thickets, $\mathrm{j}$ - psammophilous and xerothermic grasslands, $\mathrm{k}$ - ruderal communities 1 - meadows and pastures, $\mathrm{m}$ - species of undetermined phytosociological status. 


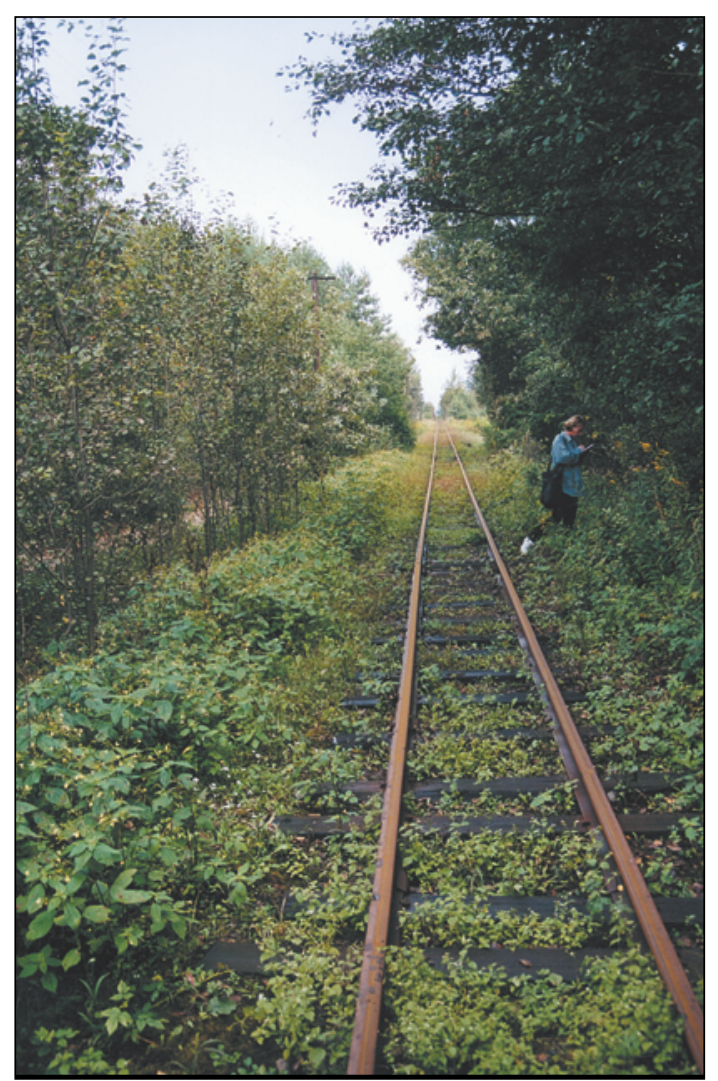

Fig. 3. Impatietum parviflorae association on the track of the narrow gauge railway.

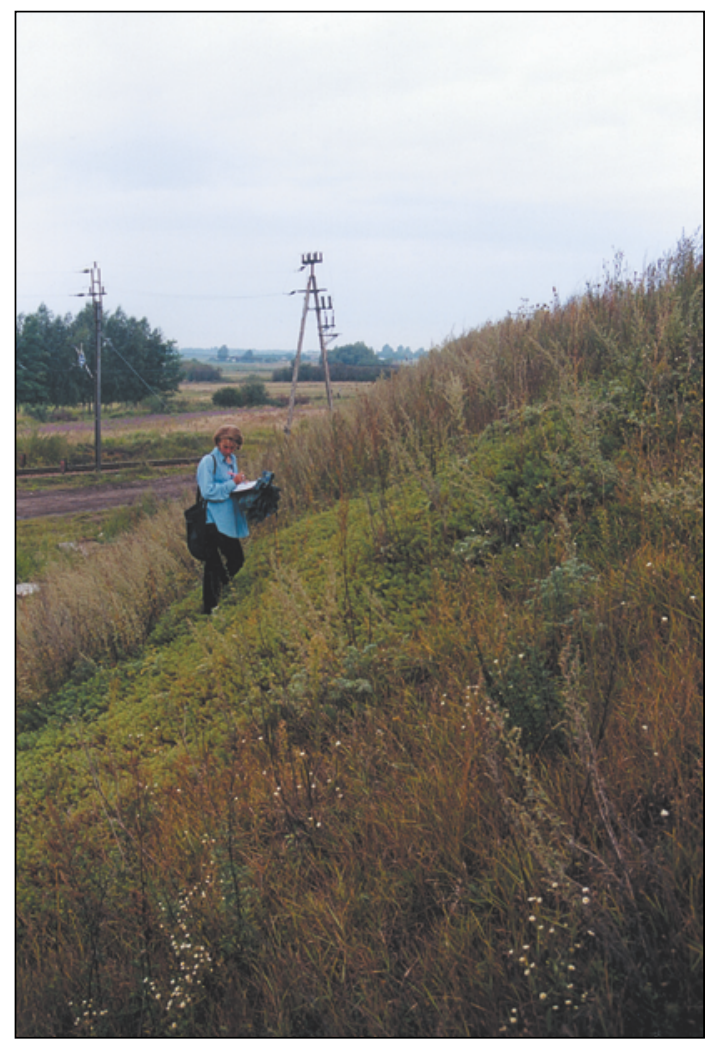

Fig. 6. A patch of the community with Euphorbia cyparissias on the railway slope.

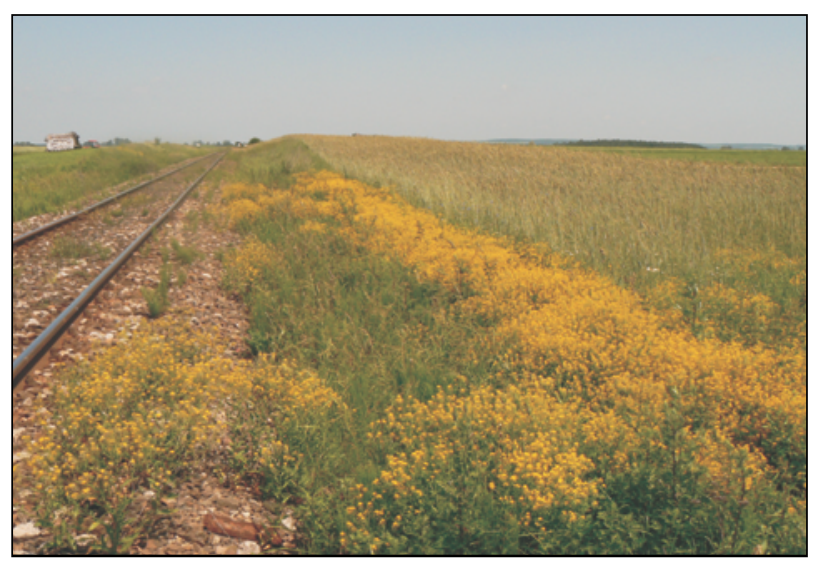

Fig. 4. A community with Rorippa austriaca at the edge of railway track.

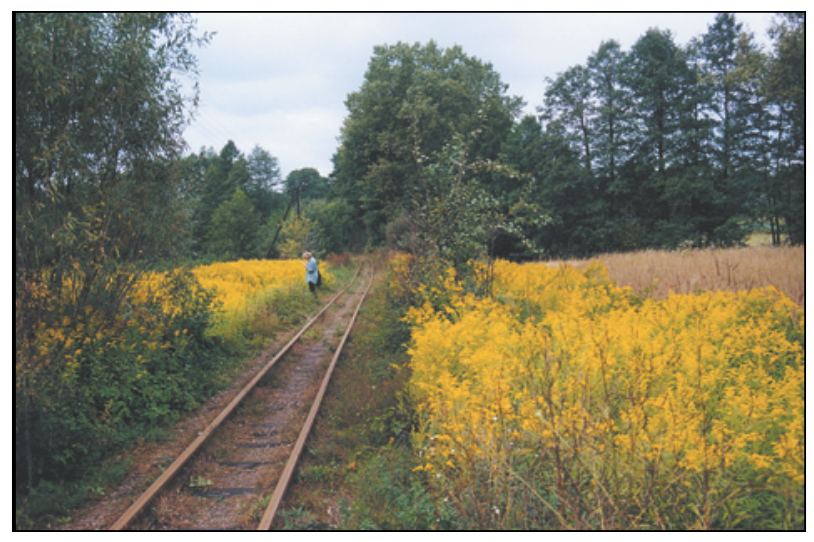

Fig. 5. Patches of Rudbeckio-Solidaginetum at the edges of the narrow gauge railway.

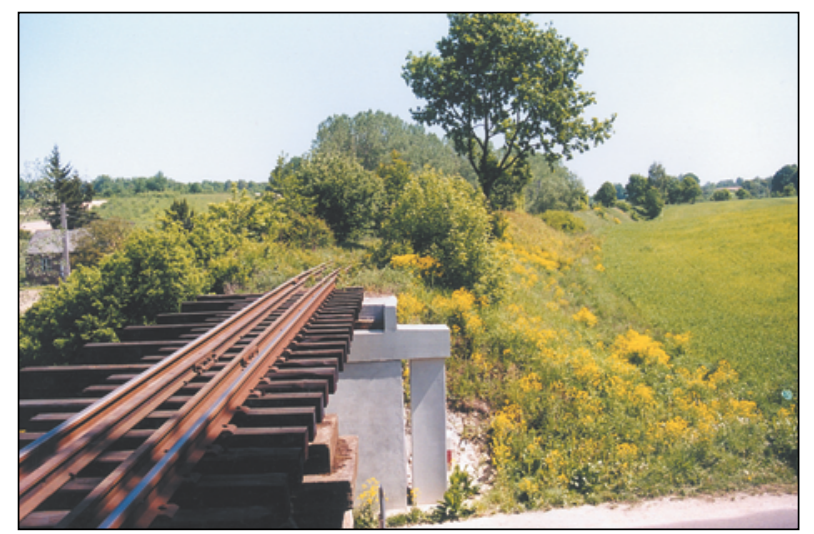

Fig.7. The patch of Bunietum orientalis in the forming stage on the slope of railway. 
elements. Also, the phytocoenoses are not linked with open or urban areas. The exception is segetal communities which are in a high degree connected with agricultural areas and were located along railways crossing agrocenoses. Generally, modified agricultural landscape creates specific conditions for pollinators. The simplified structure of plant associations decreases bee diversity and is characterized by the diminishing density of bees. The unusual density of plants in monocultures per unit square ensures the food flow in abundance, if any, only in the short period of blooming. Thus, the fact of increasing floristic diversity and the mosaic structure of plants associations, even weeds at a controlled level, will affect significantly plant restoration and conservation, the differentiation of pollinators.

Generally, the wide range of flowering of the most important nectariferous and polleniferous plants in antropogenicaly transformed phytocoenoses located along the railways areas creates the unbroken food chain for Apoidea from early spring till autumn (Tab. 2 ). However, the main food flow is provided in summer time. That is particularly important as it creates conditions for proper, balanced nutrition and food storage for nesting during winter. Thus, it influences the condition of pollinators in the next vegetation season and indirectly determines flora restoration in the environment.

\section{CONCLUSIONS}

1. Anthropogenically modified habitats along railways tracks are of high importance in the conservation of floristic variability in all environments they run across.

2. The communities with Reseda lutea, Linaria vulgaris, Papaver rhoeas, Cirsium arvense, Oenothera biennis, Viola arvensis and Potentilletum anserine or Sisymbrietum altissimi association are of low or medium stability. The mosaic of the phytocenoses in the landscape forms a rich source of nectar and pollen for Apoidea in different seasonal aspects of blooming.

3. Floristically stable are Tanaceto-Artemisietum, Rudbeckio-Solidaginetum, Echio-Melilotetum, Sambucetum nigrae, Rubo fruticosi-Prunetum spinosae associations and communities with Rosa rugosa, with Rubus caesius, with Geranium robertianum, with Pastinaca sativa, with Trifolium medium or with Euphorbia cyparissias. Beside the food supply during flowering, the phytocoenoses create refuges and nesting places for all potential pollinators.

4. The phytocoenoses formed along railways crossing agrocenoses are often the only areas in the landscape which increase floristic diversity and the mosaic structure of plant associations, thus they positively affect the differentiation of pollinators or even enable the survival of wild Apoidea in agricultural landscape.
5. Proper management efforts aimed to maintain the mosaic of phytocoenoses with its potential diversity of flowering plants may have important effects for the ecological position and conservation of bees in the environment.

\section{REFERENCES}

Banaszak J., 1992. Natural resources of wild bees in Poland as compared to the other European countries. W: Banaszak J (ed.) Natural Resources of Wild Bees in Poland. Pedagogical Univ. Bydgoszcz: 16-26.

Carreck N., Williams I., 1998. The economic value of bees in the UK. Bee World 79(3): 115-123.

Celka Z., 2004. Atlas rozmieszczenia roślin naczyniowych na grodziskach Wielkopolski. Wydawnictwo Naukowe Bogucki, Poznań.

Jackowiak B. 1990. Antropogeniczne przemiany flory roślin naczyniowych Poznania. / The anthropogenic changes of vascular plants in Poznań. Wydawnictwo Naukowe Uniwersytetu im. A. Mickiewicza w Pozaniu, Ser. Biol. 42, 232 ss., Poznań.

Jackowiak 1993. Atlas rozmieszczenia roślin naczyniowych w Poznaniu. Prace Zakładu Taksonomii Roślin UAM w Poznaniu, 2: 1-409.

Jabłoński B., Kołtowski Z., 1995. An attempt to outline the changes in the forage base of bees in Poland. In: Changes in fauna of wild bees in Europe. Pedagogical Univ., Bydgoszcz.

Korner Ch., 2005. Atmospheric changes affect biodiversity. Proceedings International Confer. 'Biodiversity Science and Governance'. Paris 24-28, January: 119-126.

Matuszkiewicz 2001. Przewodnik do oznaczania zbiorowisk roślinnych Polski. Wyd. Nauk. PWN. Warszawa.

Mirek Z., Piekoś-Mirkowa H., Zając A., Zając M., 2002. Flowering plants and pteridophytes of Poland. A checlist. Biodiversity of Poland 1: 1-442. In. Szafer Institute.

Wrzesień M., Denisow B., 2006 a. The share of nectariferous and polleniferous taxons in chosen patches of thermophilous grasslands of the Lublin Upland. Acta Agrobot. 59(1): 213-221.

Wrzesień M., Denisow B., 2006 b. The usable taxons in spontaneous flora of railway areas of the central-eastern part of Poland. Acta Agrobot. 59(2): 95-108.

Wrzesień M., Święs F., 2006. Flora i zbiorowiska roślin naczyniowych terenów kolejowych zachodniej części Wyżyny Lubelskiej. Wydawnictwo UMCS, Lublin.

Zając A., 1978. Założenia metodyczne „Atlasu rozmieszczenia roślin naczyniowych w Polsce. / Methodological assumptions of the „Atlas of distribution of vascular plants in Poland". Wiad. Bot. 22(3): 145-155.

Zarzycki K. Trzcińska-Tacik H., Różański W., Szeląg Z., Wołek J., Korzeniak U. 2002. Ecological indicator values of vascular plants of Poland. Polish Academy of Sciences, Kraków.

Zych M., Jakubiec A. 2006 . How much is bee worth? Economic aspects of pollination of selected crops in Poland. Acta Agrobot. 59(1): 289-299. 


\section{Fitocenozy środowisk antropogenicznie przeksztalconych cenne dla Apoidea}

\section{Streszczenie}

$\mathrm{W}$ pracy podjęto próbę wskazania fitocenoz najcenniejszych pod względem zasobności w gatunki pożytkowe i wykształcających się na siedliskach w obrębie trakcji kolejowych przebiegających przez Lubelszczyznę. Dotychczas, na badanym terenie, opisano 124 fitocenozy sklasyfikowane w 12 różnych grupach synekologicznych. W $52 \mathrm{z}$ nich odnotowano znaczny udział gatunków pożytkowych. W grupie zbiorowisk ruderalnych i segetalnych (Artemisietea vulgaris, Stellarietea mediae) - 87 gat., w zbiorowiskach łąkowych i pastwiskowych (Molinio-Arrhenatheretea) - 56 gat., psammofilnych i kserotermicznych (Festuco-Brometea, Koelerio glauce-Corynophoretea canescensis) 38 gat. Mniej gatunków pożytkowych występuje w zbiorowiskach reprezentujących mezofile lasy liściaste oraz świetliste dąbrowy, tylko 29. Najbardziej uproszczone postacie mają zbiorowiska z Rumex acetosa, Reseda lutea, Linaria vylgaris, Papaver rhoeas, Cirsium arvense, Oenothera biennis, Viola arvensis oraz asocjacje Potentilletum anserine czy Sisymbrietum altissimi. Tworza one płaty o powierzchni $15-20 \mathrm{~m}^{2}$, w których gatunek diagnostyczny osiaga pokrycie $80-100 \%$, a ich trwałość jest na poziomie średniej lub małej. Do stabilnych florystycznie należą natomiast asocjacje: Tanaceto-Artemisietum, Rudbeckio-Solidaginetum, Echio-Melilotetum, Sambucetum nigrae, Rubo fruticosi-Prunetum spinosae oraz zbiorowiska z Rosa rugosa, z Rubus caesius, z Geranium robertianum, z Pastinaca sativa, z Triforium medium czy z Euphorbia cyparisias. Utrzymują się one długo na rozległych powierzchniach $-20-50 \mathrm{~m}^{2}$.

Utrzymanie mozaiki fitocenoz na siedliskach antropogenicznie przekształconych, w tym w obrębie linii kolejowych, ma decydujace znaczenie w ochronie różnorodności florystycznej i procesach adaptacyjnych pszczołowatych. 